\title{
Mine site rehabilitation - are we reinventing the wrong wheel?
}

DJ Williams The University of Queensland, Australia

\begin{abstract}
Mine site rehabilitation generally aims to produce a safe, stable and non-polluting post-mining landscape that serves some agreed post-mining land use. Historically, the presumed post-mining land use has generally driven the rehabilitation process, often regardless of whether the adopted land use matches the pre-mining land use or is achievable. This dictates the flattening of the mine waste landform and the choice of surface cover applied. In the past, the adopted post-mining land use has often been grazing, which dictates that steep (usually angle of repose) mine waste slopes be flattened substantially, and that the surface be topsoiled and grassed. The tops of surface dumps and tailings surfaces often require reshaping to enhance surface drainage or water management prior to capping, topsoiling and grassing. The outer slopes of waste dumps and tailings storage facilities are generally flattened to allow access for equipment, topsoiling and grassing, possibly with the aim of allowing grazing. Even where grazing is not to be the post-mining land use, slope flattening, topsoiling, and grassing are often adopted. Whether or not grazing is the adopted post-mining land use, it may not be utilised, and a grass cover may be difficult to establish and even more difficult to sustain. Further, the limited extent to which steep mine waste slopes can be flattened generally results in slope angles that are still too steep for grazing use, and are prone to erosion, particularly if covered with topsoil and the grass cover is inadequate. This historical approach to mine site rehabilitation has led to repeated failures of flattened, topsoiled and grassed steep mine waste slopes and of regraded, capped, topsoiled and grassed dump tops and tailings. Increasingly, the establishment and sustainability of ecological functionality is seen as the key to achieving a safe, stable, and non-polluting post-mining landscape. Hence, it is argued that ecological function should be the preferred driver of mine site rehabilitation over the post-mining land use, since it better addresses the accepted rehabilitation aims. The paper presents a history of the conventional approach to mine site rehabilitation governed by slope flattening, topsoiling and grass covers, illustrated with global examples of mine site rehabilitation failures due to the adoption of those practices. These include examples from gold mining in Johannesburg, surface coal mining in Australia, and metalliferous mining in Australia, and focusses on the rehabilitation of steep mine slopes in tailings, spoil or waste rock.
\end{abstract}

\section{Introduction}

The focus of mine designers, planners and operators is to cost-effectively extract the commodity from an orebody. The development of a new mine, or the expansion of an existing operation, are expensive and risky undertakings. While the engineering challenges can generally be overcome, although sometimes at considerable cost, the prime risk is the fluctuating price of the commodity over time and the cost of producing the commodity. Commodity prices are not helped by the persistent boom-bust mining cycles, in which excess demand over supply leads to a price rise, which prompts the development of new supply, which inevitably overshoots demand and causes a price drop, and the closure of the more costly operations, and so on. For every $1 \%$ excess or deficiency of supply over demand, there is roughly a $10 \%$ change in the price of a commodity, which greatly exaggerates volatility and threatens the viability of mines. To obtain finance for a new mine or an expansion, the mining company must minimise the initial capital cost, which the financial instrument of net present value (NPV) accounting achieves through the adoption of a conservatively high discount factor. This delays non-immediate expenditure. 
While mine closure and rehabilitation are addressed from an early stage, conventionally little rehabilitation is carried out until towards the completion of mining and processing (Williams 2014). The ongoing operation and completion of a mine remain uncertain due to the vagaries of commodity prices. This makes mine planning for closure difficult until the latter stages of mining and processing. However, the key reason for the delay to expenditure that may enhance closure outcomes is the forecasting of costs on an NPV basis, rather than on a full cost or accrual accounting basis. This avoids expenditure in the short-term that may mitigate subsequent and consequent rehabilitation difficulties and costs. When rehabilitation is undertaken, it has to contend with any unintended consequences of minimising early expenditure, and can be very expensive.

The global objectives of mine site rehabilitation are fairly unambiguously to produce a safe, stable, and non-polluting post-mining landscape that serves some agreed post-mining land use. However, the historical rehabilitation of mined landscapes globally has often been driven by the presumed post-mining land use, which is often grazing, requiring slope flattening, topsoiling and grass covers. It has also been driven by the presumed expectations of regulators and stakeholders. Further, the conventional approaches to mine site rehabilitation, although flawed, are generally accepted by regulators and stakeholders without the need to prove their effectiveness and sustainability against accepted rehabilitation objectives. Mine site rehabilitation practice has not been driven by the development of approaches that best meet these well-accepted rehabilitation objectives. In the relatively few cases where unconventional rehabilitation approaches have been promoted to better meet rehabilitation objectives, they are required to be proven against (flawed) conventional approaches.

\section{History of mine site rehabilitation}

In the following sections, a history of the approach to mine site rehabilitation governed by slope flattening, topsoiling and grass covers is presented, illustrated with global examples of the failures, and occasional or partial successes, consequent on this approach. The examples include gold mining in Johannesburg, surface coal mining in Australia, and metalliferous mining in Australia, and focusses on the rehabilitation of steep mine slopes in tailings, spoil or waste rock.

\subsection{Rehabilitation of Johannesburg's gold tailings dumps from 1910 to 1991}

In the early years of gold mining in the Witwatersrand from 1910, the prevailing near legal vacuum presented little obstacle to the disposal of waste rock; cyanide-rich, acid-generating sand and slimes; mine-affected waters; and spent process chemicals (based on the excellent expose by Reichardt and Witkowski (2014)). Reichardt and Witkowski (2014) argued that the advance of applied science and engineering is rarely linear or logical. It is far more often subject to economic, political and personality issues. The history of South Africa's mine site rehabilitation from 1910 to 1991 is a good exemplar of the theme of this paper, in that there has been an ongoing focus on a topsoil and grass cover over gold tailings dumps despite this solution continually failing, as described in the following summary of the findings of Reichardt and Witkowski (2014). An early view of the gold tailings dumps up to $100 \mathrm{~m}$ high bordering Johannesburg is shown in Figure 1 (after Mason 2012). 


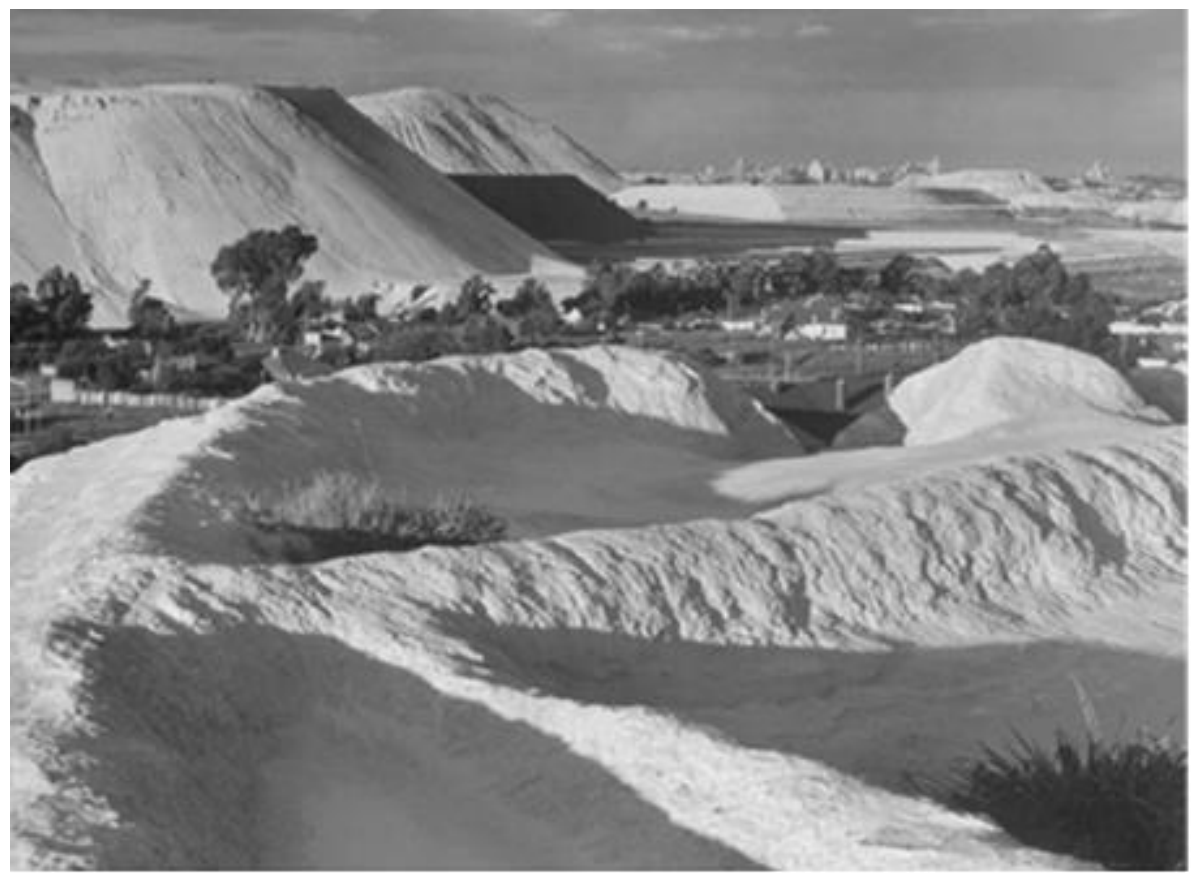

Figure 1 Early view of the gold tailings dumps up to $100 \mathrm{~m}$ high bordering Johannesburg

The year 1911 is generally cited as the beginning of pollution control on the Witwatersrand, when regulation was gazetted to prevent air-borne dust pollution. In the following two decades, the direct covering with rock or soil and spraying with sewage sludge or salts of mining wastes to suppress dust were explored. Improved economic conditions prompted greater attention to dust suppression. Planting was also trialled and, in some cases, repeated multiple times following multiple failures. Grasses, which were easier to establish than shrubs and trees, were also found to be more sensitive to harsh and acidic conditions due to their shallow rooting, requiring ongoing watering and the ongoing addition of ameliorants. Applying debris on dumps provided some dust suppression and often assisted vegetation establishment. The longer timeframe required to establish woody species belied their greater longevity and sustainability over grasses.

The 1930s saw the emergence of an expert in the field in Professor John Phillips, Head of Botany at the University of the Witwatersrand. Recognising the industry's desire for a quick solution, Phillips concentrated his efforts on the ecology of drought- and acid-tolerant grass species, ignoring woody species. However, he discouraged vegetation field trials, and spraying sludge pumped from underground workings over dumps remained the main dust suppression method. By the early 1950s, when mining wastes covered about 9,000 ha of land, the proximity of urban and industrial expansion required improved dust suppression, and water demand and pollution by the mining industry emerged as additional key issues.

In recognition of the escalating problems, between 1951 and 1956, the Chamber of Mines of South Africa engaged the Council for Scientific and Industrial Research (CSIR) to investigate the construction and stabilisation of tailings dumps, which soon demonstrated that coatings would be prohibitively expensive, with no guarantee of success. This realisation led to the abandonment of this approach for the next 20 years, and a return to grass covers, despite their poor record under drought and acidic conditions. The renewed preference for grass covers was spear-headed by Brian Cook of Gold Fields, who planted over 3 years 1,500 field plots with over 100 species; mainly grasses. The efforts of the CSIR and Cook were combined amid mounting pressure to find a solution to the mounting pollution problem. By 1963, Cook had developed a generally successful method of establishing, although not necessarily sustaining, grass covers on tailings dump tops and less acidic dump slopes. The approach was adopted as the best available technology, although its longevity had not been proven. 
From 1964 to 1974, with the gold price essentially fixed, the focus was on cost control, including limiting the cost of addressing dust. While grass covers remained the chosen strategy, there was growing acknowledgement that they needed to be sustainable. In 1964, the Chamber of Mines introduced a Trust Fund Model, which still governs the financial provisioning of post-closure environmental liabilities in South Africa. From 1967 the Chamber's Vegetation Unit could not grass the tops of slimes dams fast enough to keep pace with their expanding completed footprint. This occurred amid increasing failures of the grass covers with age, mainly associated with fluctuating acidity, which was related to rainfall patterns. Rainfall not only sustains the grasses, it also flushes oxidation products into the dump and beyond the reach of the roots. The response to surface acidity was to add further lime. By late 1970, a third of the effort of the Vegetation Unit was devoted to cover the cost of maintenance and repair of grass covers, and closure certificates were being withheld. This situation was exacerbated by South Africa's fluctuating economic fortunes during the early 1970s.

Following a resurgence in the gold price in 1973, the Vegetation Unit expanded its work dramatically. By 1976, about 4,190 ha of the total estimated 8,500 ha of abandoned tailings dumps on the Witwatersrand had been grassed. However, the continuing high gold price made the re-processing of the dumps economic, and the interest shifted from rehabilitation to re-processing of the dumps, involving hydraulic mining (Figure 2). Re-processing presented the opportunity to extract both gold and sulphides, potentially rendering the residual tailings non-acid generating, and interest in developing a long-term tailings dump rehabilitation strategy diminished.



Figure 2 Hydraulic mining of gold tailings in Johannesburg prior to re-processing (source: Tailings.info 2015)

Interest in developing a long-term and cheaper tailings dump rehabilitation strategy re-emerged in 1978, which the Chamber appointed Fred Cartwright to pursue. Amid industry uncertainty at a time of increasing labour unrest (the Soweto Riots) and costs, and the associated 20-fold increase from 1972 to 1979 in the costs of applying a grass cover, Cartwright sidelined grass covers and closed the Vegetation Unit's laboratory. Cartwright argued (correctly) that the substantial additions of soil, fertiliser and water to leach out the acidity made grass covers unsustainable and cost-prohibitive. He promoted the use of the so-called COMET device as a measure of surface erodibility under rainfall. A Comet Erosion Index above a certain value (a jet pressure of $60 \mathrm{kPa}$ was promoted) was deemed to indicate a non-erodable surface, not requiring a cover. COMET Erosion Index values below this threshold would require the application of a sealant. However, while some tailings hard-panned sufficiently to be non-erodable by rainfall or wind, they 
could still generate dust on trafficking due to the breaking of the hard-pan. Cartwright failed to have the COMET accepted and in late 1982, John Greig of the Chamber of Mines forced the reinstatement of grass covers as the best available technology, without specifying their required longevity.

In 1983, the mining industry was for the first time being asked some hard questions by regulators about gold tailings dump rehabilitation standards, to which they had no clear answers. In the vacuum left by the failure of the COMET and the diminished Vegetation Unit, Professor Koos van Wyk of Potchefstroom University championed a form of dry land rehabilitation utilising new drought-tolerant Eragrostis varieties of grass which began to be taken up by the industry. In 1988, Professor Geoff Blight of the University of the Witwatersrand showed the COMET method to be technically flawed.

Since 1991, attempts at grass covers have persisted, with continuing varied success, (Figure 3). Gold tailings dumps in Johannesburg continue to showing deteriorating grass covers on slopes and to be reclaimed for re-processing (Figures $4(\mathrm{a})$ and (b)). New topsoil and grass covers continue to be constructed on gold tailings dump slopes, while at the same time severe dust storms continue to plague Johannesburg (Figures 5(a) and (b)).

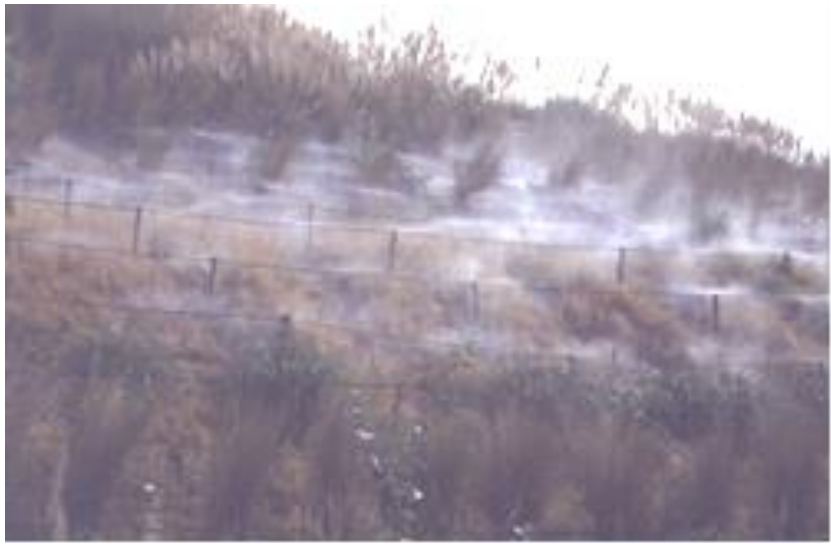

(a)

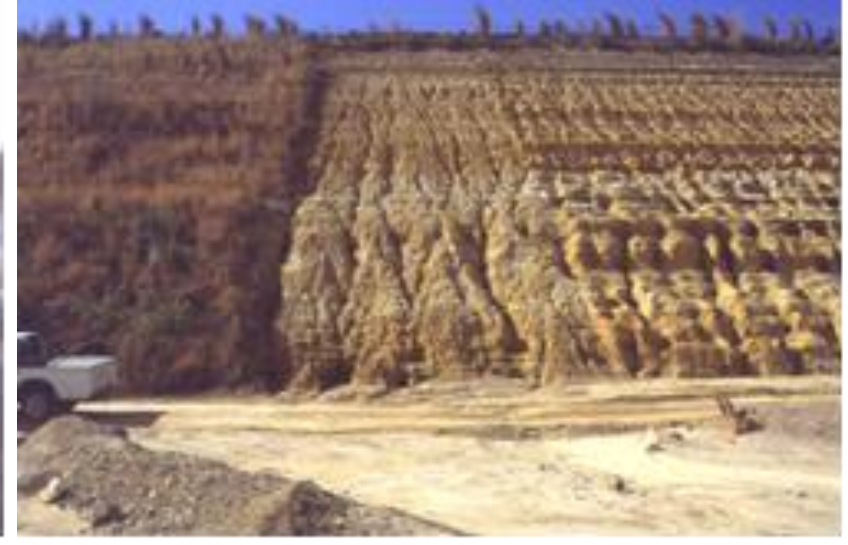

(b)

Figure 31996 grass covers on Johannesburg gold tailings dumps, showing: (a) watering to leach acidity, and (b) grassed, and eroding smoothed and unsmoothed slopes

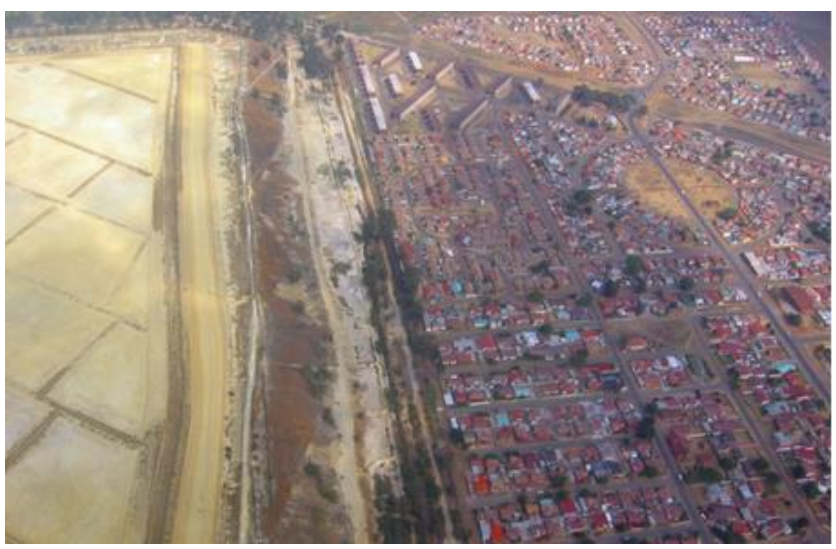

(a)

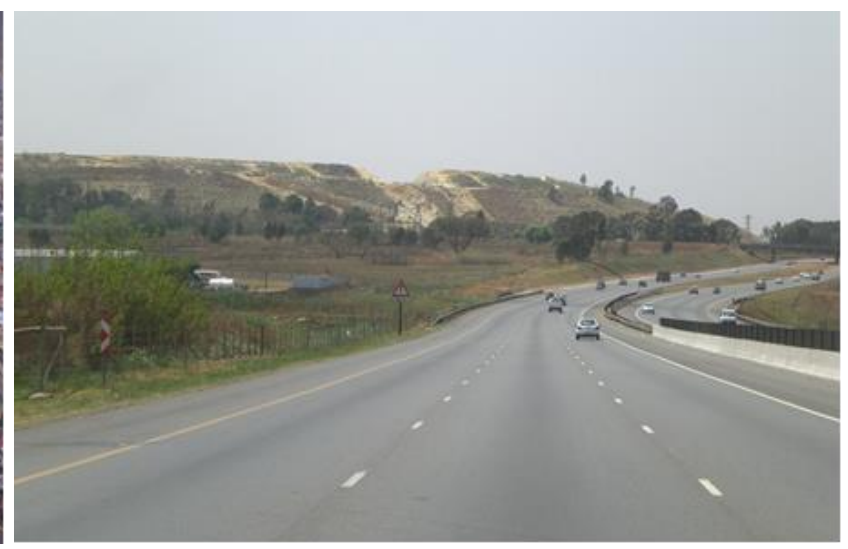

(b)

Figure 4 Gold tailings dumps in Johannesburg, showing: (a) deteriorating grass cover of slope adjacent to suburbs (source: Future Terrains 2014), and (b) partially re-claimed gold tailings in for re-processing (source: Sprott Gobal 2013) 


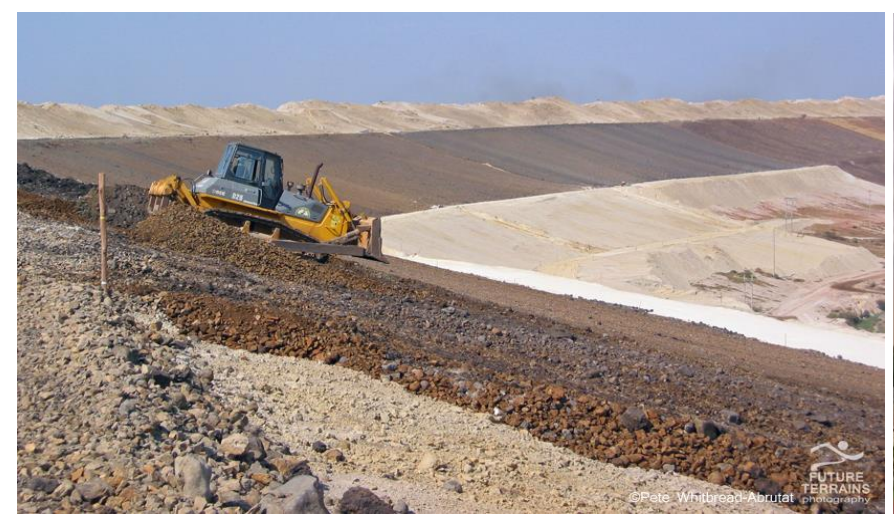

(a)

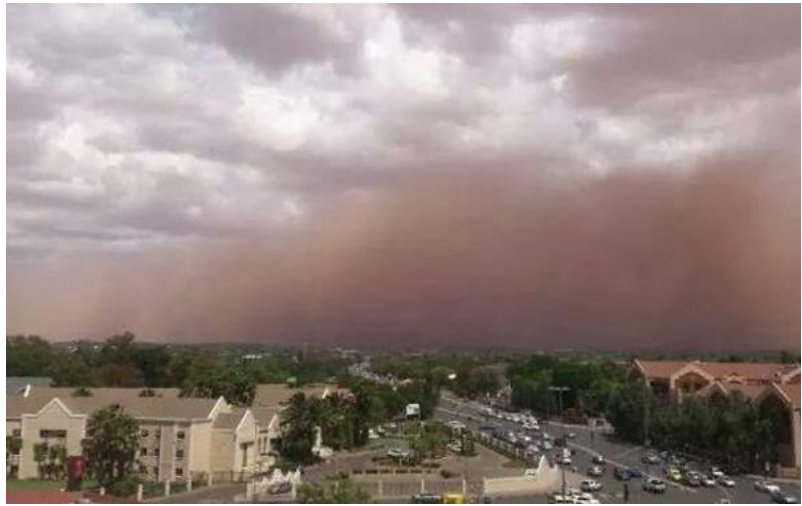

(b)

Figure 5 Continuing: (a) practice of topsoil and grass covers on gold tailings dump slopes (source: Future Terrains 2014), and (b) dust storms (source: Enca 2014)

Topsoil and grass covers have waxed and waned as a perceived solution to dust from gold tailings dumps in Johannesburg over the last 105 years since gold mining began there, and their effectiveness has been variable and often short-lived. It is clear that the research and development required to address the identified issues of dust and water pollution from gold tailings dumps have been far from rigorous and that effective solutions continue to evade the industry and society. Further, it is clear that while economic conditions are a strong driver of action, strong personalities and politics have a disproportionate influence on the approaches adopted, and they are not always productive.

\subsection{Provisions of the Central Queensland Coal Associates Act}

On 28 January 1968, the Central Queensland Coal Associates Agreement Act (CQCA) 1968 - Schedule 1 (CQCA Act 1968), the Queensland State Government entered into an agreement with Utah Development Company (later BHP Coal Pty Ltd) and Mitsubishi Development Pty Ltd (later combined under BHP Billiton Mitsubishi Alliance, or BMA) for the development of four open strip coal mines in the Bowen Basin Coalfields of Central Queensland, Australia, covering about $6,257 \mathrm{~km}^{2}(2,444$ square miles). The coal mines were, from north to south, Goonyella, Peak Downs, Saraji and Norwich Park (Figure 6).

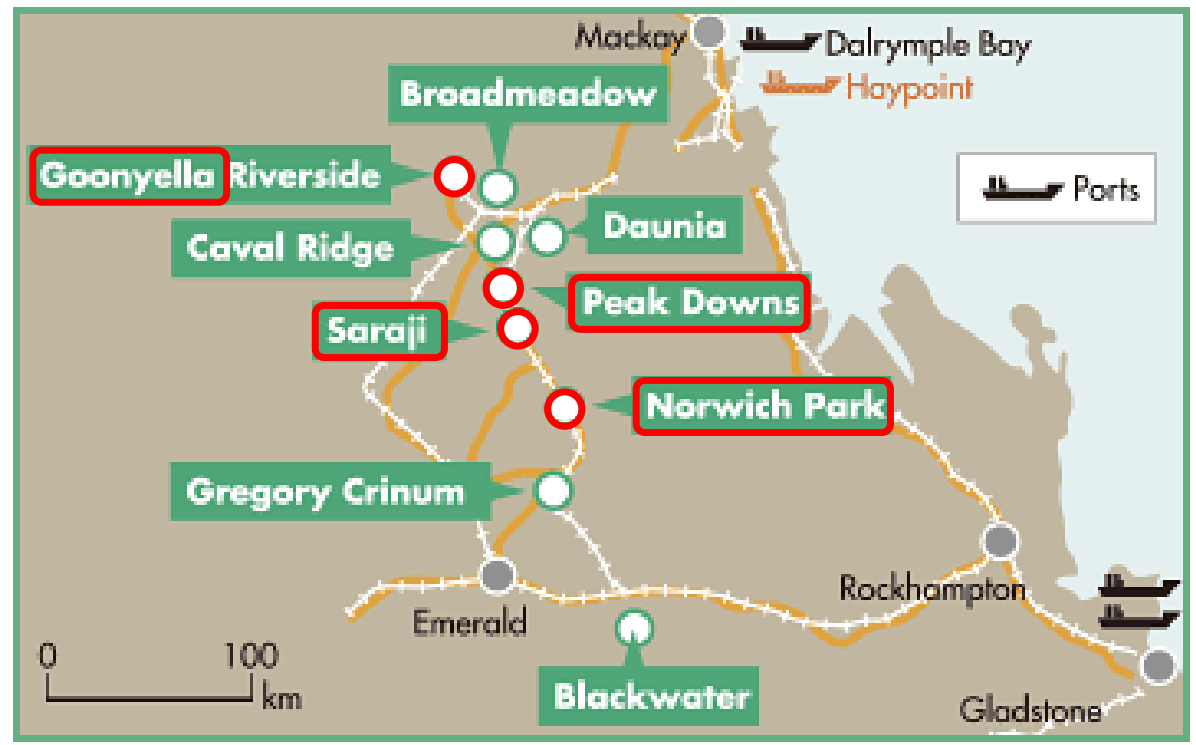

Figure 6 Locations of mines developed under the CQCA Act (source: Mitsubishi Corporation 2015)

Under the CQCA Act, the operators of the four mines covered by the Act were required, prior to open strip mining, to lodge an amount of AUD 110/ha (AUD 50/acre) for disturbed land. This cash lodgement was 
refundable upon the restoration of the surface to not less than its former value for purposes connected with grazing. No refund was due if the surface was of no value for purposes connected with grazing, or a proportionate amount was refundable based on the value of the land for purposes connected with grazing as compared with its former value for such purposes. As a result of the requirement of a grazing post-mining land use for the four mines covered by the CQCA Act, this was adopted by the majority of mines in the Bowen Basin Coalfields, including new mines. The mines employed environmental officers to manage spoil rehabilitation, and, because the post-mining land use was to be grazing the appropriate discipline required of this role was agricultural science, since this discipline was skilled in establishing and maintaining pasture grasses. Professor Clive Bell of the Agricultural Science Department at The University of Queensland saw an opportunity to provide appropriately-trained graduates for mine environmental officer roles. He introduced a number of tailor-made courses for undergraduates and established the highly successful Centre for Mined Land Rehabilitation, which remains very active under Professor David Mulligan, to train Masters and Doctoral students in mined land rehabilitation. Professor Bell's graduates and postgraduates filled over half of the newly-established mine environmental officer roles established.

To facilitate a post-mining grazing land use, the spoil piles were flattened from the angle of repose (nominally $35^{\circ}$ or 1 in 1.4 or $70 \%$ ) to typically $8.5^{\circ}$ (1 in 6 or 17\%). Contour banks were used to reduce slope lengths in an effort to reduce erosion, and the flattened slopes were topsoiled and grassed. Rock-lined downslope drains were constructed to manage rainfall runoff. Introduced grasses were planted, since there was a shortage of native grass seed and native grasses were found to be more difficult to establish. However, there was little utilisation of rehabilitated spoil slopes for grazing. This was partly because the grass cover was too poor to support grazing, but also because local graziers (and their cattle) considered the slopes still too steep, the grass was of poor quality, and there was no water available on the slopes (Figure 7).



(a)

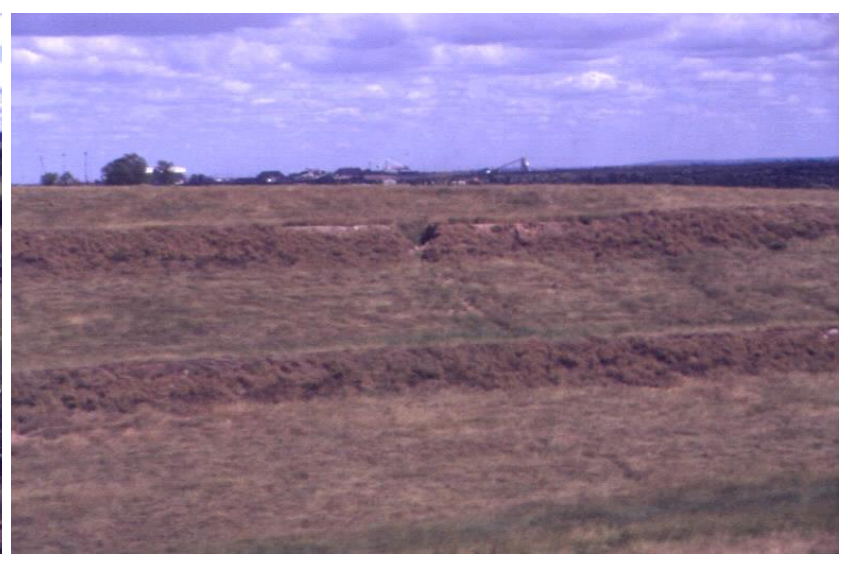

(b)

Figure 7 Bowen Basin spoil piles rehabilitated for grazing: (a) recently flattened, contour-banked, topsoiled and grassed, and (b) established grass cover showing overtopping of a contour bank

In amendments to the CQCA Act dated 31 December 1997 (CQCA Act 1997), the minimal rental rate of AUD 1/acre/year charged under the Act, for access to old coal mining leases to 1 January 1998, was increased to AUD 15/ha for all leases. More significantly, the potentially refundable lodgement of only AUD 50/acre for disturbed land was deemed totally inadequate to meet the rehabilitation cost if the land were left disturbed. The improved environmental management and security arrangements put in place under the Mineral Resources Act made this amendment redundant, and the stipulation that the land be returned to grazing was rescinded. This provision was replaced by a significantly increased security in the form of cash or bank guarantee, which included the AUD 50/acre lodgement.

Despite the rescinding of the requirement of a grazing post-mining land use, there was no immediate change to the rehabilitation practice aimed at this land use. What had more effect was a significant rise in 
the rail freight rates charged by the Queensland State Government to haul coal from the mines to the ports. The extra cost impost is believed to have resulted in a reduced rate of spoil rehabilitation.

\subsection{New South Wales prescriptive approach to spoil rehabilitation}

In the Hunter Valley Coalfields of New South Wales, Australia, the early rehabilitation of spoil areas was also predicated on a grazing post-mining land-use and became prescriptive. Angle of repose spoil piles were generally required to be flattened to slopes angles that, in general, do not exceed $10^{\circ}$ to the horizontal ( 1 in 5.7 or 18.3\%; Hannan 1978, 1984). This slope angle of $10^{\circ}$ was decided following a survey of natural slopes in the Liddell-Ravensworth-Jerry's Plains area. From a great many measurements, the median slope angle was found to be $10^{\circ}$. It was decided that, if spoil piles were to blend naturally with the surrounding topography, their flattened slopes should not exceed this angle. It is interesting to note that the prescribed angle of $10^{\circ}$ is a little steeper than the angle independently adopted in the Bowen Basin Coalfields of Queensland, given that the Bowen Basin is more remote and less productive than the Hunter Valley. However, the topography of the Bowen Basin is significantly flatter than the Hunter Valley.

Where access roads, power lines, or water courses limit the distance to which spoil can be spread, final slope angles may be up to $14^{\circ}$ ( 1 in 4 or $25 \%$ ). Slope angles in excess of $14^{\circ}$ were deemed permissible in small areas, provided that the operator demonstrates that they can be stabilised and revegetated. Unfortunately, where a particular slope angle is specified, albeit a limiting value, it tends to become the default slope angle to which all spoil slopes are flattened. The resulting landscape hence appears unnatural.

Temporary contour banks, dams and silt-traps, are required to prevent the sedimentation and contamination of watercourses by material eroded from bare spoil areas. The spacing between contour banks will limit catchment sizes (Hannan \& Bell 1993), but they run the risk of overtopping and/or piping failure if left in place.

Prior to topsoiling, all rocks in excess of $0.5 \mathrm{~m}$ in size, which might seriously interfere with later cultivation operations, are required to be removed from the surface. This is unfortunate since rocks would also be effective in limiting surface erosion, particularly while a vegetation cover is establishing. Topsoil, previously stripped from the mined area, is required to be spread over the flattened spoil, to a thickness increasing for steeper slopes. This presumably is in recognition that a greater depth of topsoil will be lost to erosion on steeper slopes. After the pasture is well-established and the risk of further serious erosion seems minimal, surface rocks exceeding $0.2 \mathrm{~m}$ in size are required to be removed or buried, again reducing the resistance to surface erosion. This requirement is aimed at making the area safe for vehicle traffic and stock after it has been returned to grazing. Typical Hunter Valley spoil pile rehabilitation for grazing is shown in Figure 8.

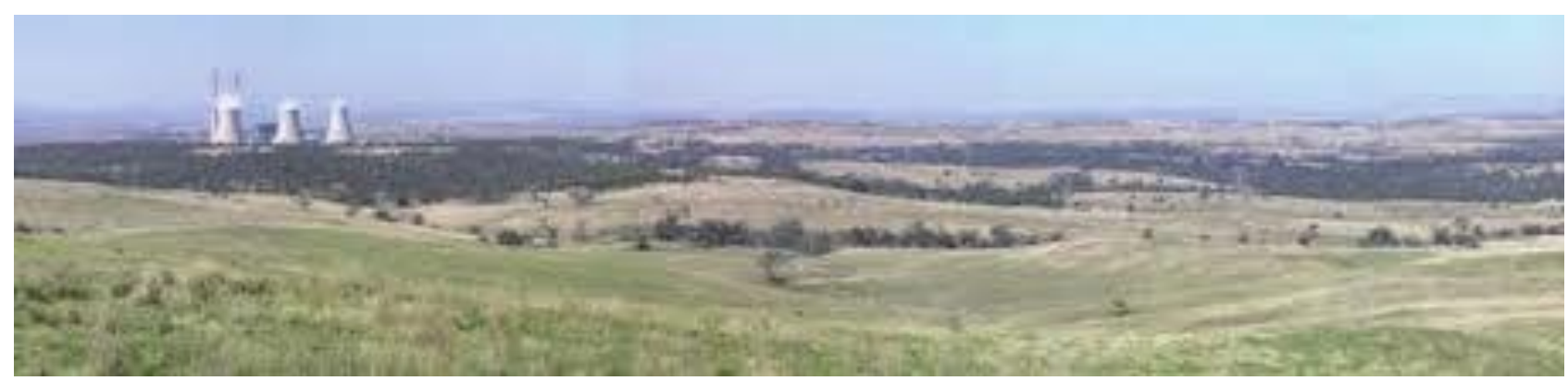

Figure 8 Typical Hunter Valley spoil pile rehabilitation for grazing (source: NSW DPI 2007)

Many of the Hunter Valley spoil materials are sodic and tend to crust on the surface, restricting rainfall infiltration and penetration by roots. At depth, however, they may remain relatively free-draining. Since the spoil is generally elevated above the surrounding terrain, the combined effect is to retard the entry of moisture and to speed the passage of any infiltration into the deeper layers, where it is unavailable to all but very deep-rooted vegetation. Low infiltration results in correspondingly high runoff. On the long, uniform slopes of flattened spoil piles, high runoff rates can cause severe erosion in a short space of time. This is exacerbated by the absence of rock to provide erosion resistance, and the loss of valuable topsoil 
that would promote revegetation. Since revegetation is critical if land is to be stabilised, improved in appearance, and given some productive capability, these hydrological problems are major ones to be overcome.

Native grasses have significant disadvantages for initial revegetation of mine sites in the Hunter Valley. They have low germination percentages, are tussocky in habit, and extremely slow to establish, and hence are neither favoured for grazing nor effective in minimising erosion. Further, seed is difficult to obtain in sufficient quantities. Stockpiling of topsoil for periods of longer than about six months has an adverse effect on stored plant seeds and micro-organisms. The material is then virtually sterile when placed over flattened spoil and the amount of vegetation that volunteers is insignificant. The survivors tend to be poorer species, which then compete with the sown species. Unfortunately, the nature of strip coal mining dictates that the bulk of the stripped topsoil must be stockpiled for considerable periods of time.

As the land area disturbed by mining increases, natural watercourses become buried beneath many metres of spoil and the diversion of runoff from its natural flow path becomes inevitable. Early in the life of a mine, serious thought should be given to selecting final discharge points for runoff at the junctions between disturbed and undisturbed land. All reshaping work should be directed towards developing a drainage pattern that will direct runoff to these points. The gradient and cross-sectional area of newly formed drainage lines must be adequate to convey the anticipated flows without causing erosion damage.

Careful reshaping can preserve the continuity of the valleys and ridges formed by the saw-tooth spoil piles resulting from open strip mining, although blending several ridges together will reduce their number. Filling of the valleys can be adjusted so that they lead progressively, at a sustainable gradient, towards one or more ramps or haul roads that will ultimately be converted into major watercourses. Dams constructed in the valleys serve two purposes. In the initial stages, when they will very likely leak, they will ease the load on the new watercourses while vegetation is becoming established. Later, when rehabilitation is complete, they will serve as stock water supplies.

\subsection{Coal mine spoil rehabilitation in Australia from late 1990s}

The over 4-fold flattening of spoil pile slopes for rehabilitation purposes increased their catchment 4-fold, and crushed or buried coarse-grained rock, making the surface smoother and increasing the runoff (Williams 2001a). The topsoil placed for revegetation purposes was finer-grained than the spoil and often more erodible (Figure 9(a)). Further, while coalfields rainfall typically averages about $600 \mathrm{~mm} / \mathrm{yr}$, it can be highly variable and dominated by intense rainfall events that exacerbate erosion. Contour banks and downslope drains concentrate rainfall runoff 10 to 100-fold and inevitably fail (Figure 9(b)). Recognising this, contour banks became seen to be temporary, to be removed once revegetation was established.

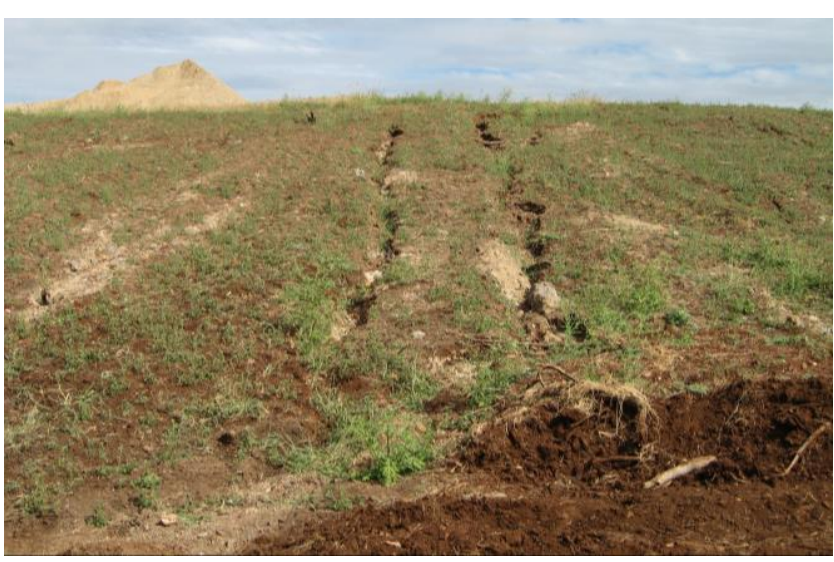

(a)

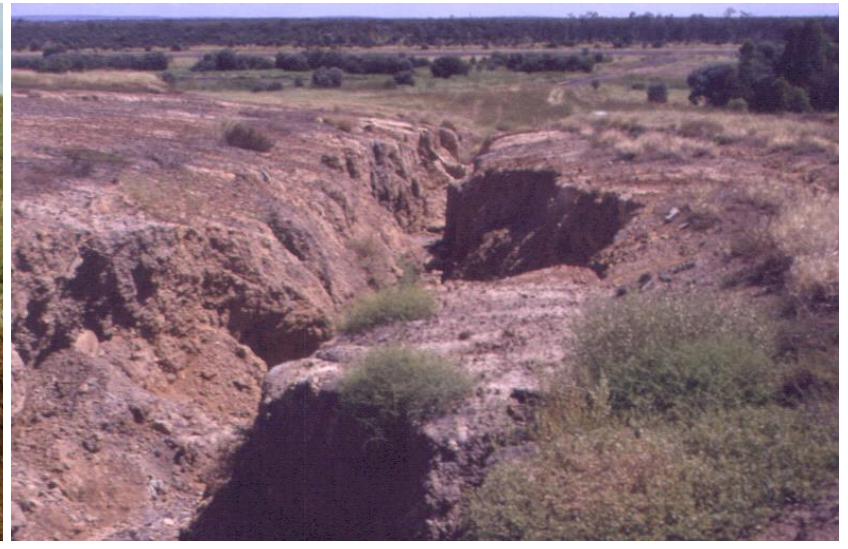

(b)

Figure 9 Flattened Bowen Basin spoil piles, showing: (a) rill erosion of grassed topsoil, and (b) failing downslope drain 
From the late 1990s, a number of mines in the Bowen Basin Coalfields gradually changed their post-mining land use from grazing to native habitat (Williams 2001b, 2001c). However, this typically did not involve a change in the flattening of the spoil piles from the angle of repose to $8.5^{\circ}$. It merely meant a change in the vegetation from pasture grasses to native shrubs, trees and grasses (Figure 10(a)). At Curragh Mine, alternating strips of grasses on topsoil and trees on coarse reject or directly on spoil were adopted (Figure 10(b)).

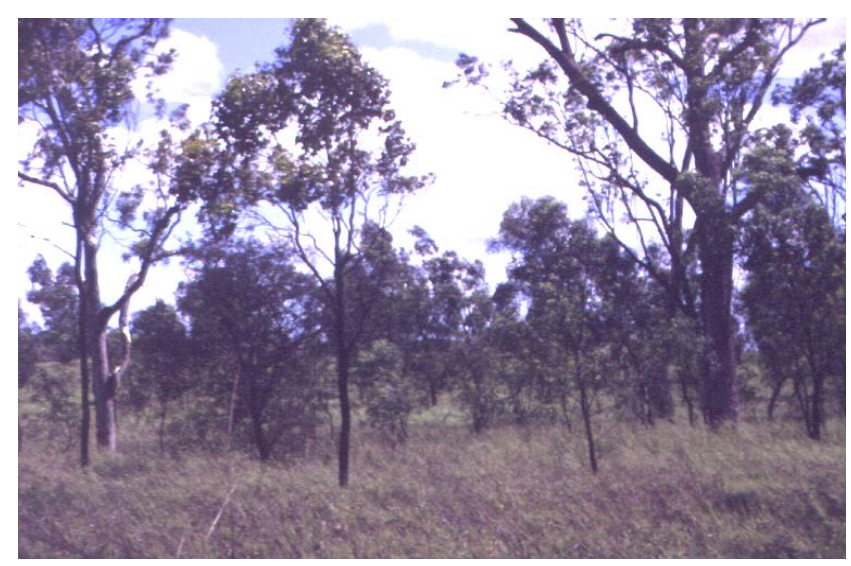

(a)



(b)

Figure 10 Flattened Bowen Basin spoil piles, rehabilitated for: (a) native habitat, and (b) alternating grasses and trees

There is no need to flatten spoil pile slopes to this extent for native habitat establishment. Spoil pile slopes could have been left at the angle of repose if the spoil was capable of revegetating directly (Figure 11(a)). At a number of mines in the Bowen Basin, internally-drained or water-harvesting spoil landforms were trialled successfully. They involved flattening the tops of the dragline saw-tooth spoil piles to form small ponds with a perimeter bund to retain water, and retaining the outer slopes at the angle of repose (Figures 11(b) and 12).

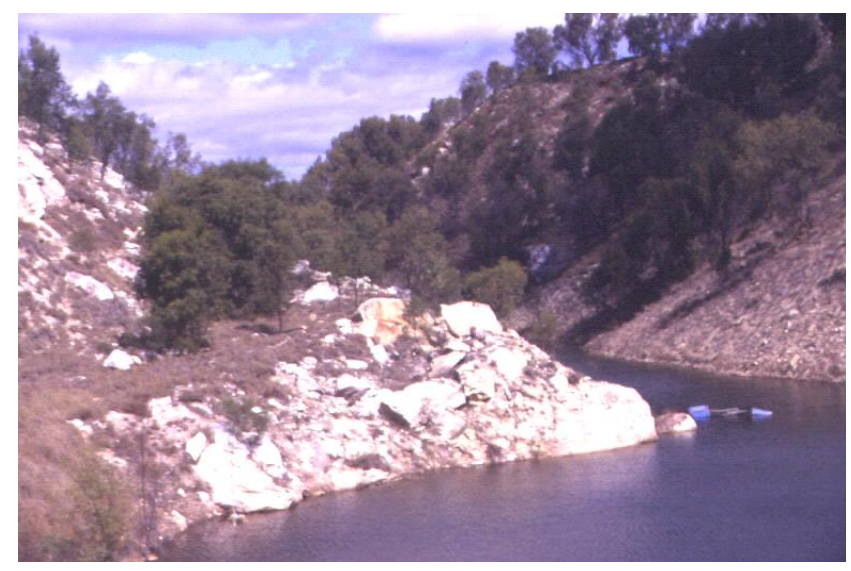

(a)



(b)

Figure 11 Alternative rehabilitation of Bowen Basin spoil piles: (a) volunteer native shrubs, trees and grasses on angle of repose sandstone slopes, and (b) native trees planted on flattened spoil pile tops, and native grasses and shrubs on angle of repose spoil slopes 




(a)

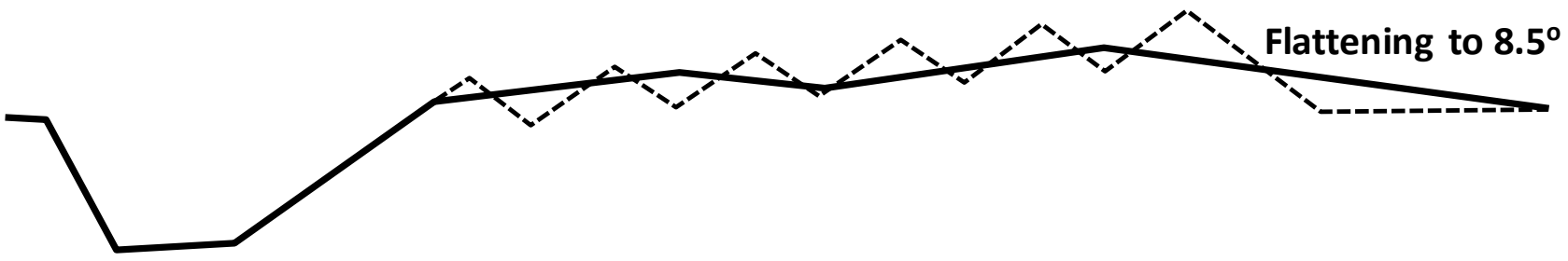

(b)

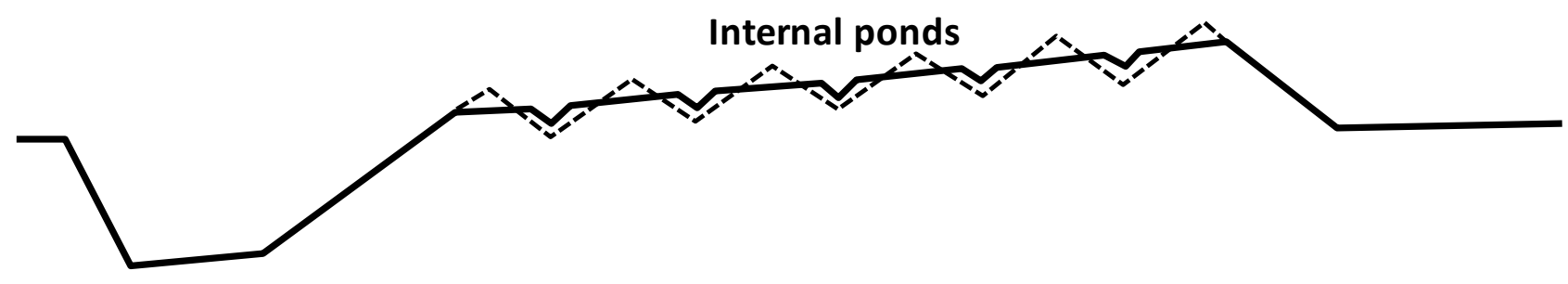

(c)

Figure 12 Alternative rehabilitation of Bowen Basin dragline saw-tooth spoil piles: (a) as-constructed, (b) flattened to $8.5^{\circ}$, and (c) internal ponds

As the depth of the open pits increased, not all of the spoil could be excavated by dragline, and the upper overburden had to be pre-stripped by shovel and truck. The pre-strip was typically hauled to fill the valleys between the earlier dragline saw-tooth spoil piles, removing the need to flatten internal slopes. The ongoing placement of pre-strip spoil also meant that much of the spoil area remained active, and was not available to be rehabilitated.

In the Hunter Valley, an increasing number of open pit mines became shovel and truck only operations, which presented the opportunity to place the spoil to progressively form the desired final landscape. However, the prescribed general maximum $10^{\circ}$ final slope angle constrained the final landform, and little advantage could be taken of this opportunity. The focus continued to be minimising the short-term cost of spoiling, with little regard to the cost of eventual rehabilitation.

\subsection{Rehabilitation of metalliferous mine surface waste rock dumps in Australia}

The rehabilitation of metalliferous mine surface waste rock dumps in Australia, as elsewhere, is dominated by the perceived need to flatten the outer angle of repose slopes (Williams 2006). However, the flattening of angle of repose waste rock slopes is generally not required to ensure geotechnical stability, and is likely to reduce erosional stability due to the increased catchment, higher runoff and reduced erosion resistance.

Loose-dumped waste rock dump ravels at the angle of repose of the material of 35 to $40^{\circ}$, depending mainly on the particle size distribution of the waste rock, which in turn depends mainly on its degree of weathering. Since the internal friction angle of durable waste rock is typically about $45^{\circ}$, about $8^{\circ}$ higher than the angle of repose of the material on loose dumping (Leps 1970), the factor of safety against geotechnical slopes instability is over 1.3. Even degradable waste rock is likely to remain stable at its angle of repose, provided that the phreatic surface does not rise within the dump.

If an angle of repose waste rock dump slope is to be flattened, the maximum slope angle will be a function of the safe operation of plant to effect the flattening. Dozers can safely push down an angle of repose slope 
to a maximum slope of about 1 in $2\left(26.5^{\circ}\right)$, and a dozer can safely traverse across the contour on a slope of up to about 1 in $3\left(18.5^{\circ}\right)$. As a result, waste rock dump slopes are conventionally flattened to 1 in 3 for rehabilitation purposes. However, this angle is still steep and dozer manufacturers do not warranty their dozers if used continuously at such slope angles due to their effect on the circulation of hydraulic fluid to lubricate the tracks.

The conventional rehabilitation of an angle of repose waste rock dump slope, which involves the flattening of the slope angle to less than half the angle of repose, the construction of contour and downslope drains to manage rainfall runoff, and topsoiling, can result in a final slope with adequate geotechnical stability but inadequate erosional stability (Figures 13 and 14). While pushing down the slope angle improves geotechnical stability, dozing crushes and buries the coarser-grained boulders and smooths the surface, thus increasing rainfall runoff and reducing erosion resistance. The fine-grained growth medium cover is particularly prone to erosion, especially until revegetation becomes established, if it does.



(a)

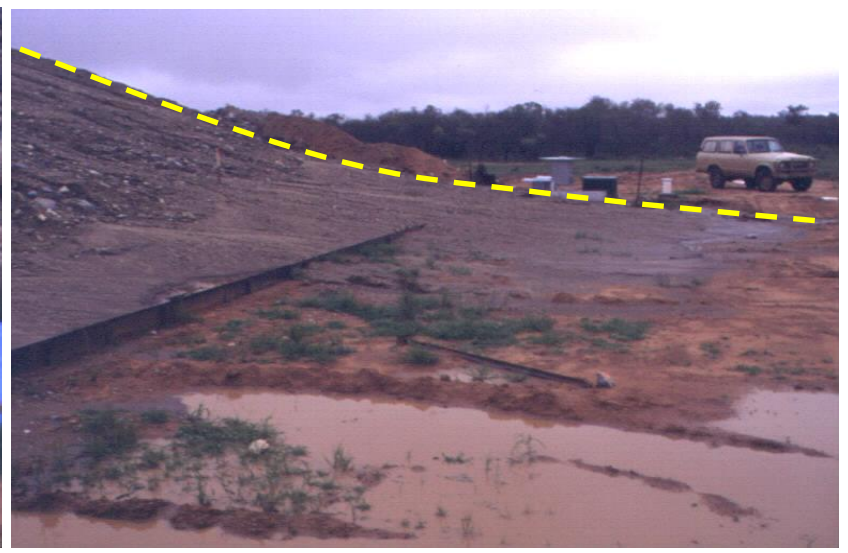

(b)

Figure 13 Waste rock dump erosion due to a $25 \mathrm{~mm}$ rainfall event, showing: (a) negligible erosion off an angle of repose slope, and (b) substantial erosion of a slope flattened to 1 in 3 and covered with a $500 \mathrm{~mm}$ thickness of growth medium

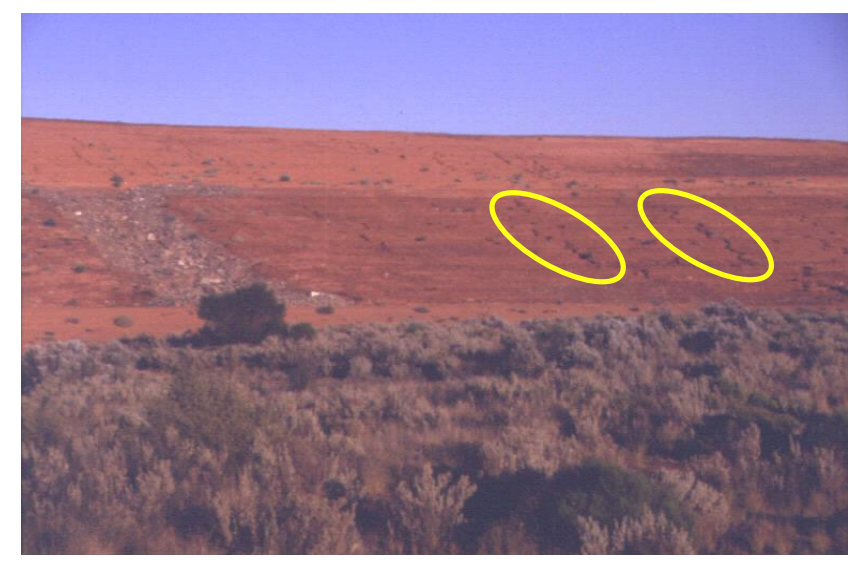

(a)



(b)

Figure 14 Waste rock dump flattened to 1 in 3, with contour and downslope drains constructed, and topsoiled, showing: (a) rilling away from downslope drain on first rainfall event, and (b) deep erosion gullies through thick topsoil over time

The concentration of rainfall runoff in contour and downslope drains makes the slope more prone to tunnel erosion and gullying, if the materials are dispersive (Figure 15). If the rainfall incident on the top of the dump is shed over the dump sides, it is concentrated about 10 -fold. Rainfall runoff will be concentrated a further 10 -fold or more in downslope drains. Hence, a modest $10 \mathrm{~mm}$ rainfall event can be magnified to 
over $1,000 \mathrm{~mm}$ of runoff. If the contour drains have low points and/or are not adequately sloped towards the down slope drain, there is a distinct possibility that the rainfall runoff will not reach them and they will be even more ineffective (Figure 14(a)).

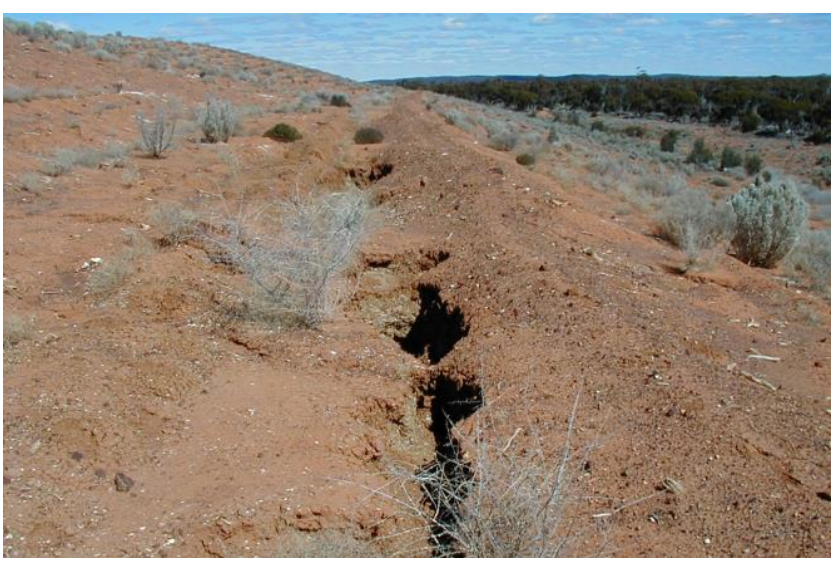

(a)

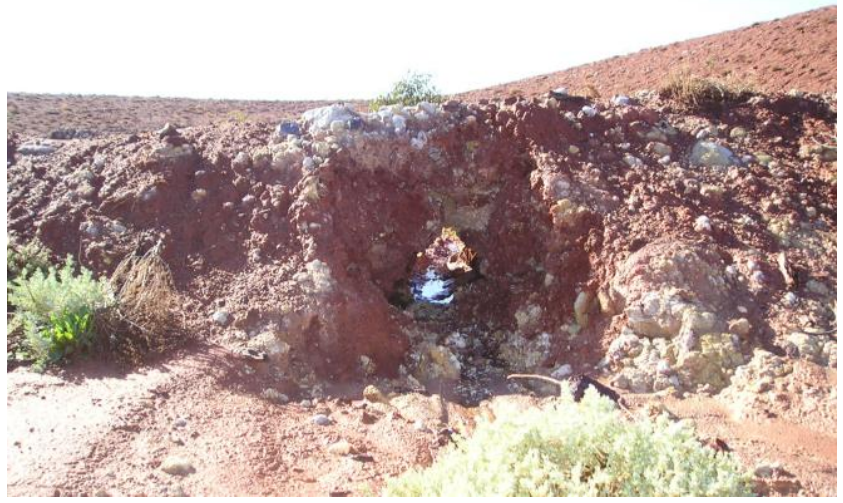

(b)

Figure 15 Contour drain in dispersive waste rock, showing: (a) tunnelling inlets along contour drain, and (b) major tunnel outlet, prior to collapse to form a gully

Alternative approaches to creating stable final slopes, drawing upon surrounding natural analogues, offer the potential to produce sustainable slopes of high geotechnical and erosional stability, and improved aesthetics (Williams 2006). Natural hillslopes differ from constructed mine waste rock slopes in a number of crucial ways. While mine waste rock slopes are generally constructed and reshaped to a linear profile, natural hillslopes are generally concave-shaped, which tend to capture erosion sediment on the slope, and are of diverse angle, length, and surface texture. Natural hillslopes are protected from erosion by rock armouring, cemented cap rock, and vegetation. Mine waste rehabilitation earthworks should aim to reconstruct similar distributions of slope angles, slope lengths, vegetation patterns etc. to those pre-mining, for minimum earthworks and hence minimum cost. Fluvial geomorphic mine waste rehabilitation design principles, such as those used at BHP Billiton's La Plata and San Juan coal mines in the Badlands of New Mexico, should be employed in preference to linear engineering design principles (Figure 16).



(a)

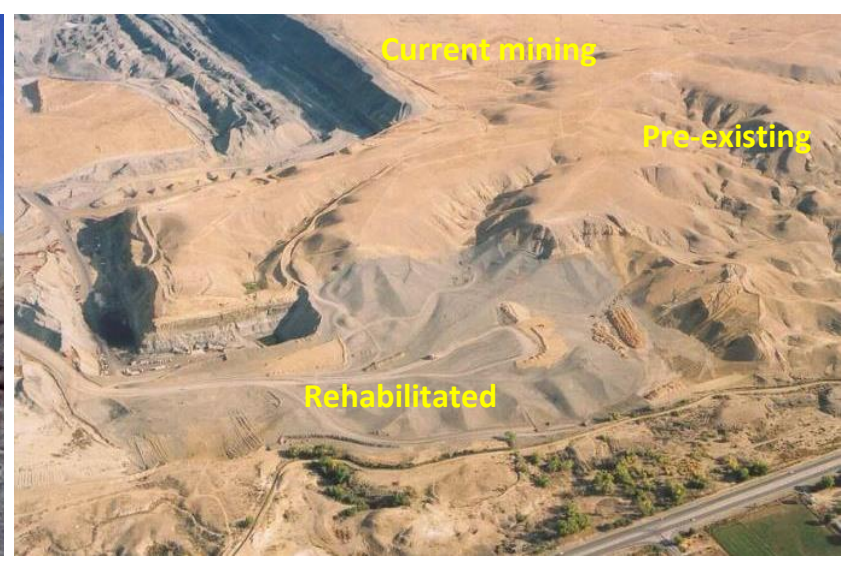

(b)

Figure 16 Fluvial geomorphic mine waste rehabilitation design principles employed at BHP Billiton's La Plata and San Juan coal mines in the Badlands of New Mexico: (a) rehabilitated hill scape, and (b) pre-existing, current mining and rehabilitated landforms 


\section{Conclusion}

The storage of mining and mineral processing wastes in surface facilities inevitably produces elevated landforms with steep outer slopes. These landforms are often of uniform geometry and the outer slopes are linear, making them stand out from diverse natural landforms. The conventional rehabilitation of these mine waste landforms focuses on flattening the outer slopes to unnatural linear profiles, likely incorporating contour and downslope drains, and the surface is generally topsoiled and grassed.

The global objectives of mine site rehabilitation are fairly unambiguously to produce a safe, stable, and non-polluting post-mining landscape that serves some agreed post-mining land use. However, the historical and ongoing rehabilitation of mined landscapes is focussed on an often flawed post-mining land use rather than on the core objectives of creating a safe, stable and non-polluting post-mining landscape. There is a reluctance to accept alternative rehabilitation approaches promoted to better meet these core objectives, and the industry and other stakeholders continue to reinvent the wrong wheel. Economic, political and personality issues often dominate, casting aside the linear and logical advance of applied science and engineering. Mine site rehabilitation should assist the natural trajectory towards sustainable mined landscapes.

\section{References}

CQCA Act 1968, Central Queensland Coal Associates Agreement Act 1968 - Schedule 1, viewed 24 August 2015 , http://www5.austlii.edu.au/au/legis/qld/consol_act/cqcaaa1968396/sch1.html

CQCA Act 1997, Central Queensland Coal Associations Agreement Amendment Bill 1997, viewed 24 August 2015, http://www.austlii.edu.au/au/legis/qld/bill_en/cqcaaab1997517/cqcaaab1997517.html

Enca 2014, Sandstorm paints Jozi city gold, viewed 24 August 2015, https://www.enca.com/south-africa/pictures-sandstormpaints-jozi-city-gold

Future Terrains 2014, Mine Closure Perspectives, viewed 24 August 2015, Available from http://www.futureterrains.org/ mineclosureperspectives-mineral-wastes/

Hannan, JC 1978, 'Rehabilitation of mined areas', Australian Mining, 70(2), pp. 34-45.

Hannan, JC 1984, Mine rehabilitation: A handbook for the coal mining industry, NSW Coal Association.

Hannan, JC \& Bell, LC 1993, 'Surface Rehabilitation', in AJ Hargraves \& CH Martin (eds), Australasian Coal Mining Practice, Monograph Series no. 12, The AusIMM, Melbourne, Australia, pp. 260-280.

Leps, TM 1970, 'Review of shearing strength of rockfill', in Proceedings of ASCE, Journal of Soil Mechanics and Foundation Engineering Division, 96(SM4), pp. 1159-1170.

Mason, JE 2012, 'Picturing the beloved country: Margaret Bourke-White', Life Magazine, and South Africa, 1949-1950, Kronos, 38(1).

Mitsubishi Corporation 2015, BHP Billiton Mitsubishi Alliance Mines, NSW Department of Primary Industry, 2007, viewed 24 August 2015, http://www.mitsubishicorp.com/jp/en/csr/sustainability/sustainability04.html

NSW DPI (New South Wales Department of Primary Industries) 2007, 'Hunter Key Site', Key Sites - Land Use to Manage Water \& Salt, viewed 24 August 2015, http://www.dpi.nsw.gov.au/_data/assets/pdf_file/0006/189852/Hunter.pdf

Reichardt, MT \& Witkowski, ETF 2014, 'South Africa's mine waste rehabilitation 1910-1991: personalities, economics, organisations and legislation that shaped the development of an applied science', in Proceedings of Mine Closure 2014, p. 18.

Sprott Gobal 2013, Elsburg tailings site, Johannesburg, South Africa, viewed 24 August 2015, http://sprottglobal.com/ natural-resource-investing/site-visits/?albumld=4437

Tailings.info 2015, Hydraulic mining of tailings, viewed 24 August 2015, http://www.tailings.info/technical/hydraulic.htm

Williams, DJ 2001a, 'Prediction of erosion from steep mine slopes', International Journal of Environmental Management and Health, 12(1), pp. 35-50.

Williams, DJ 2001b, Risk Assessment of Bowen Basin Spoil Rehabilitation - Final Report, ACARP Project No 8039, 1999-2001, p. 135.

Williams, DJ 2001c, Risk Assessment of Bowen Basin Spoil Rehabilitation - Literature Review and Commentary, ACARP Project No 8039, 1999-2001, p. 109.

Williams, DJ 2006, 'The case for revolutionary change to mine waste disposal and rehabilitation', in Proceedings of Second International Seminar on Strategic versus Tactical Approaches to Mining, Australian Centre for Geomechanics, Perth, p. 19.

Williams, DJ 2014, 'Keynote Lecture: Mine planning for the final landform', in Proceedings of Fifth International Mining and Industrial Waste Management Conference, p. 52. 